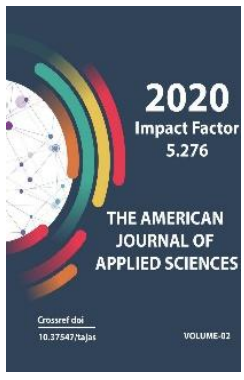

Journal Website: http://usajournalshub.c om/index,php/tajas

Copyright: Original content from this work may be used under the terms of the creative commons attributes 4.0 licence.

\section{Technology Of Modified Sodium-Aluminum Catalysts For Nitrogen Gas Purification Systems}

\author{
Mirzarakhimov Mirsolikh Sultonovich \\ Doctor Of Technical Sciences, Professor, Professor, Department Of Life Safety, Faculty Of \\ Mining And Metallurgy, Tashkent State Technical University Named After Islam Karimov, \\ Tashkent, Uzbekistan \\ Iskandarov Jakhangir Ravshan Ogli \\ Doctoral Student Of The Department “Objects Of Oil And Gas Processing" Of The Faculty Of \\ Geologybacklight, Tashkent State Technical University Named After Islam Karimov, Tashkent, \\ Uzbekistan \\ Umirzoqov Azamat Abdurashidovich \\ Doctoral Student, Department Of Mining, Faculty Of Mining And Metallurgy, Tashkent State \\ Technical University Named After Islam Karimov, Tashkent, Uzbekistan \\ Amanov Tolib Sirozhevich \\ Uzbek Institute Of Geotechnical And Non-Ferrous Metallurgy Research And Project Search \\ “O'zgeorangmetliti” Engineer Of The Mining Department Of The State Unitary Enterprise, \\ Uzbekistan
}

\title{
ABSTRACT
}

The introduction of the method of chemical trapping of nitrogen oxides in a complex with selective catalytic purification of tail gases from industrial production makes it possible to increase the service life of the catalyst regardless of the NOx concentration, create a cycle of low-waste technology and achieve significant savings in the consumption of the scarce AVK-10 catalyst ... Reuse of the spent catalyst AVK-10 in the process of cleaning tail gases of industrial production from NOx and absorption-catalytic cleaning of the latter with the use of solid waste products allows simultaneously solving environmental and economic problems in the production of weak nitric acid.

The prospect of using the waste of lead-concentrating factories as a natural sorbent-catalyst in gemological is substantiated. processes of purification of waste gases of sulfuric acid production.

The proposed chemisorption-catalytic method for purifying waste gas mixtures from sulfur dioxide does not require special preparation of a wet, high-temperature dusty gas. The use of natural materials within the framework of this method allows you to extract from them valuable raw materials - metal oxides.

\section{KEYWORDS}

Gas, chemically, mechanism, purification, removals, operating mode, oxide, sorbent 


\section{INTRODUCTION}

The results of our studies have shown that the comparatively low activity and productivity of aluminum-vanadium catalysts are due to a limited approach to the study of this catalytic system. When setting up this work, extensive studies of the $\mathrm{Al}_{2} \mathrm{O}_{3}-\mathrm{V}_{2} \mathrm{O}_{5}$ system were carried out by modifying them with oxides $\mathrm{Fe}_{2} \mathrm{O}_{3}, \mathrm{Cr}_{2} \mathrm{O}_{3}, \mathrm{NiO}, \mathrm{CaO}$, as well as alkaline and alkaline-earth elements, and the results of changing the preparation technology and heat treatment conditions were studied [1].

The influence of the nature and concentration of modifiers of iron oxide and manganese dioxide on the properties of the initial and spent catalyst AVK-10, intended for the purification of gas emissions from NOx, has been investigated. The ranges of the investigated mass fractions for iron oxide and manganese dioxide were 0.06 to 7.0; the latter were introduced both separately and in various combinations [2]. The choice of added additions was made based on the analysis of scientific and technical literature and the properties of the oxides of the corresponding additives.

\section{MATERIAL AND METHODS}

To establish the modifying effect of the added additives separately and in their various combinations, complex studies were carried out using the methods: electron paramagnetic resonance (EPR), IR spectroscopy, EDS, and the temperature-programmed reduction curve (CTPR). The study of the activity of the synthesized catalysts was carried out in laboratory, experimental and industrial installations for the purification of tail gas from NOx.
A series of alumovanadium catalysts prepared by various methods and containing $10 \% \mathrm{~V}_{2} \mathrm{O}_{5}$, $0.1-10 \%$ wt. Was synthesized and studied. $\mathrm{Fe}_{2} \mathrm{O}_{3}$ and (or) 0.1 to $10 \mathrm{wt} \%$. $\mathrm{Cr}_{2} \mathrm{O}_{3}$, and (or) $1 \% \mathrm{NiO}, \mathrm{CaO}$, as well as oxides of alkali and alkaline earth metals [3]. To obtain the catalysts, the corresponding salts of the active components were mixed with alumina hydrate, impregnated with a molded $\gamma-\mathrm{Al}_{2} \mathrm{O}_{3}$ solution of ammonium metavanadate and nitric acid salts of modifying additives, as well as an industrial alumovanadium catalyst AVK10 with solutions of modifier salts. After drying (in the case of a mixed-type catalyst) and drying, the catalysts were subjected to heat treatment at $580^{\circ} \mathrm{C}$ for $6-8 \mathrm{~h}$. 
Table 1 shows the compositions of the compositions applied to the AVK-10 catalyst.

Table 1

Compositions of compositions applied to the AVK-10 catalyst, wt\%

\begin{tabular}{|c|c|c|c|c|c|c|c|}
\hline $\begin{array}{l}\text { No. of } \\
\text { samples }\end{array}$ & $\begin{array}{l}\mathrm{Fe}_{2} \mathrm{O}_{3} \% \\
\text { мacc }\end{array}$ & $\mathrm{Cr}_{2} \mathrm{O}_{3}$ & $\mathrm{NiO}$ & $\mathrm{CoO}$ & $\begin{array}{c}\mathrm{Li}_{2} \mathrm{O}, \mathrm{Na}_{2} \mathrm{O} \\
\mathrm{K}_{2}, \mathrm{Rb}_{2} \mathrm{O} \\
\mathrm{Cs}_{2} \mathrm{O} .\end{array}$ & $\begin{array}{l}\mathrm{ZnO}, \mathrm{CaO}, \\
\mathrm{BeO}, \mathrm{MgO}\end{array}$ & $\mathrm{B}_{2} \mathrm{O}_{3}$ \\
\hline $1-7$ & - & $0,1-10$ & - & - & - & - & - \\
\hline 8-14 & $0,1-10$ & - & - & - & - & - & - \\
\hline 15 & - & - & 1,0 & - & - & - & - \\
\hline 16 & - & - & - & 1,0 & 1,0 & - & - \\
\hline $17-21$ & - & - & - & - & - & 1,0 & - \\
\hline $21-24$ & - & - & - & - & - & - & 1,0 \\
\hline 25 & - & - & - & - & - & - & - \\
\hline 26 & 4,0 & 1,0 & - & - & - & - & - \\
\hline 27 & 4,0 & - & 1,0 & - & - & - & - \\
\hline 28 & 4,0 & - & - & 1,0 & - & - & - \\
\hline 29 & 4,0 & - & - & - & - & - & - \\
\hline
\end{tabular}

Preliminary tests of synthesized samples based on AVK-10 showed that, in terms of the degree of purification of model gas mixtures from NOx at a temperature of $240-350^{\circ} \mathrm{C}$, catalysts with additions of $\mathrm{Fe}_{2} \mathrm{O}_{3}, \mathrm{Cr}_{2} \mathrm{O}_{3}, \mathrm{NiO}$ and $\mathrm{CaO}$ are superior to samples containing alkaline and alkaline earth elements. The latter exhibit a promoting effect only at the beginning of the experiment, and then a decrease in the activity of the initial AVK-10 catalyst is observed [4].
In this regard, further studies of catalyst samples containing alkaline, alkaline earth

oxides, and boron oxide were discontinued.

The introduction of oxides of iron, chromium, nickel and cobalt into the composition of the AVK-10 catalyst, both individually and in combinations, does not significantly affect its physicochemical and structural-mechanical properties. In this case, the mechanical strength of the catalysts increases from 40 to $45 \mathrm{~kg} / \mathrm{cm} 2$, 
the bulk density from 0.55 to $0.7 \mathrm{~kg} / \mathrm{l}$, the total porosity slightly decreases, although the specific surface area of the samples increases from 180 to $195 \mathrm{~m} 2 / \mathrm{g} \quad .$. According to the literature data, an increase in the specific surface area can be explained by the appearance of a secondary microporous structure upon the introduction of modified additives [5]. Similar changes in the physicochemical and structural and mechanical properties are observed in modified catalysts prepared on the basis of the $\mathrm{\gamma}-\mathrm{Al}_{2} \mathrm{O}_{3}$ support, obtained from aluminum hydroxide of the Dneprodzerzhinsk Petrochemical Complex. Modified catalysts based on this support are characterized by higher mechanical strength (65 $78 \mathrm{~kg} / \mathrm{cm} 2)$, bulk density ( 0.7 $0.84 \mathrm{~kg} / \mathrm{l}$ ) and porosity (64 80\%) as compared to catalysts based on AVK - 10 . These the changes are mainly related to the substrate. Differences in carriers may be due to the structural properties of the initial aluminum oxide hydrate, the presence of impurities, rheological properties and moisture of the formed pastes. Consequently, the prehistory of carriers of the same composition plays an important role in the synthesis of vanadium catalysts for the reduction of nitrogen oxides [6].

Some hardening effect of modifiers is explained by the filling of the contact points between the carrier particles during heat treatment.

To prepare mixed-type alumovanadium catalysts, the calculated amount of $A_{1}$ $(\mathrm{OH}) 3$ with an absorption coefficient of $35 \%$ was loaded into a mixer and $\mathrm{NH}_{4} \mathrm{VO}_{3}$ dissolved in water with the addition of oxalic acid was added thereto. To modify the catalyst, the calculated amount of nitric acid salts of $\mathrm{Cr}, \mathrm{Fe}, \mathrm{Ni}$, and $\mathrm{Co}$ was dissolved separately. The mixture was thoroughly mixed until a homogeneous mass was obtained [7]. Paste with pp. 28 $32 \%$ were molded on a $5 \times 5 \mathrm{~mm}$ screw press. After drying for $12-16 \mathrm{~h}$, the granules were dried at $110-120^{\circ} \mathrm{C}$ and calcined at $580--600^{\circ} \mathrm{C}$ for $6--8 \mathrm{~h}$.

When $\mathrm{Fe}_{2} \mathrm{O}_{3}, \mathrm{Cr}_{2} \mathrm{O}_{3}, \mathrm{NiO}$ and $\mathrm{CaO}$ are added to the $\mathrm{Al}_{2} \mathrm{O}_{3}-\mathrm{V}_{2} \mathrm{O}_{5}$ system, its mechanical strength increases from 87 to $100 \mathrm{~kg} / \mathrm{cm} 2$. At the same time, the bulk density of the contacts increases, and their porosity and specific surface area decrease. An increase in strength with the introduction of nitric acid salts of modifying additives is due to peptization of aluminum oxide hydrate and the formation of a partial nitrate boehmite under the action of a weak solution of nitric acid released during dissolution of nitric acid salts of the corresponding modifiers. The decrease in porosity and specific surface area is explained by the sintering of small pores during the calcination of amorphous pseudoboehmite particles under the action of iron, chromium, nickel and cobalt oxides [8].

\section{RESULTS}

To optimize the component composition of the modified alumovanadium catalyst, samples of the following composition (wt, ppm) were synthesized:

ABK-10 Fe2O3-0,06 7.0

ABK-10 MnO2-0,06

ABK-10 $\mathrm{Fe} 2 \mathrm{O} 3-5,0+\mathrm{MnO} 2-0,067.0$

$A B K-100,06$ 5.0+ MnO2-4 
The catalysts were prepared by impregnating an AVK-10 sample (substrate), previously dried at $473523^{\circ} \mathrm{K}$, with aqueous solutions of iron and manganese nitrate salts or their mixture.

The concentration of these solutions corresponded to $350450 \mathrm{~kg} / \mathrm{m} 3$. Depending on the content of the added additives, the impregnation 'was carried out once or twice. Then the catalysts were dried at $473523^{\circ} \mathrm{K}$ and, to convert the salts into the corresponding oxides, they were subjected to final heat treatment at $853873^{\circ} \mathrm{K}$. With the introduction of $\mathrm{Fe}_{2} \mathrm{O} 3$ and $\mathrm{MnO}_{2}$, a symbatic increase in the mechanical strength of the AVK-10 catalyst is observed, and the strength increases with an increase in the concentration of the added additives. The specific surface area of the catalyst also increases from 1.8 * 105 to $2.0 * 105 \mathrm{~m} 2 / \mathrm{kg}$. With the combined introduction of $\mathrm{Fe}_{2} \mathrm{O}_{3}+\mathrm{MnO}_{2}$, the formation of catalysts is accompanied by a relatively large increase in mechanical strength, but a decrease in porosity.

Table 2

Comparative Activity of Modified $\mathrm{A1}_{2} \mathrm{O}_{3}-\mathrm{V}_{2} \mathrm{O}_{5}$ Catalysts Prepared by Various Methods

\begin{tabular}{|c|c|c|c|c|c|c|}
\hline \multicolumn{4}{|c|}{$\begin{array}{l}\text { The composition of the introduced modifiers, } \\
\qquad \text { wt\% }\end{array}$} & \multicolumn{2}{|c|}{$\mathrm{NO}_{\mathrm{x}}$ content,\% vol. } & \multirow{2}{*}{$\begin{array}{c}\text { Power } \\
\text { CLEANING,\% }\end{array}$} \\
\hline $\mathrm{Fe}_{2} \mathrm{O}_{3}$ & $\mathrm{Cr}_{2} \mathrm{O}_{3}$ & $\mathrm{NiO}$ & $\mathrm{CoO}$ & $\begin{array}{l}\text { before } \\
\text { cleaning }\end{array}$ & $\begin{array}{c}\text { after } \\
\text { cleaning }\end{array}$ & \\
\hline \multicolumn{7}{|c|}{ AVK-10 based catalysts } \\
\hline 5,0 & - & - & - & 0,38 & 0,0076 & 98,0 \\
\hline 4,0 & 1,0 & - & - & 0,42 & 0,0306 & 92,7 \\
\hline 4,0 & & 1,0 & - & 0,46 & 0,0501 & 89,1 \\
\hline 4,0 & - & - & 1,0 & 0,39 & 0,0362 & 90,7 \\
\hline \multicolumn{4}{|c|}{ Exodus. AVK-10 } & 0,39 & 0,0860 & 77,8 \\
\hline \multicolumn{7}{|c|}{$\mathrm{V}_{2} \mathrm{O}_{5}$ modifiers for $\gamma-\mathrm{Al}_{2} \mathrm{O}_{3}$} \\
\hline $90 \%$ & - & - & - & 0,37 & 0,1030 & 72,1 \\
\hline 5,0 & - & - & - & 0,42 & 0,0227 & 94,6 \\
\hline- & 1,0 & - & - & 0,38 & 0,0770 & 79,8 \\
\hline- & - & 1,0 & - & 0,36 & 0,0770 & 78,6 \\
\hline
\end{tabular}




\begin{tabular}{|c|c|c|c|c|c|c|}
\hline- & - & - & 1,0 & 0,39 & 0,0815 & 79,1 \\
\hline \multicolumn{7}{|c|}{ Mixed Vanadium Catalysts } \\
\hline - & - & - & - & 0,40 & 0,134 & 66,4 \\
\hline 5,0 & - & - & - & 0,38 & 0,050 & 86,9 \\
\hline - & 1,0 & - & - & 0,42 & 0,119 & 71,6 \\
\hline- & - & 1,0 & - & 0,39 & 0,120 & 69,3 \\
\hline - & - & - & 1,0 & 0,40 & 0,129 & 70,1 \\
\hline
\end{tabular}

Therefore, their promoting role is minimized, although there is an increase in activity by $4-20 \%$ compared to the original alumovanadium catalyst [9].

Modified catalysts prepared on the basis of $\gamma-\mathrm{A}_{12} \mathrm{O}_{3}$ from pseudoboehmite occupy an intermediate position in activity:

AVK-10> $V_{2} 05$ on $\gamma-\mathrm{A}_{12} \mathrm{O}_{3}>\mathrm{V}_{2} 05$ on $\gamma$-A12O3 (mixed). The results show that iron oxide is characterized by the highest promoting efficiency. Modification of the catalyst with iron oxide in combination with other oxides does not give a sufficient synergistic effect. Thus, when the sample contains $4 \% \mathrm{Fe}_{2} \mathrm{O}_{3}$, the activity of the AVK-10 catalyst increases by $10 \%$, with $5 \% \mathrm{Fe}_{2} \mathrm{O} 3$ - by $20 \%$, while the introduction gives:

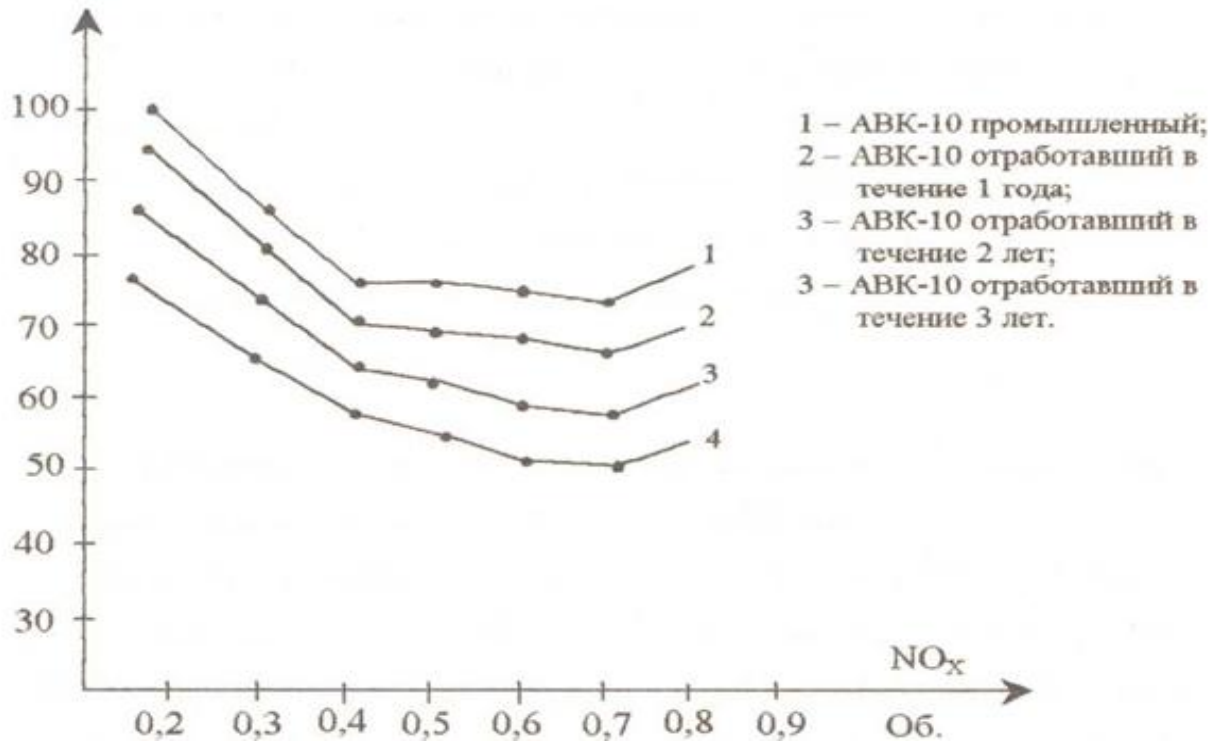


Figure: Activity of spent catalysts AVK-10 depending on the volume fraction of $\mathrm{NO}_{\mathrm{x}}$ in the gas mixture.

$$
\begin{gathered}
4 \% \mathrm{Fe}_{2} \mathrm{O}_{3}+1 \% \mathrm{Cr}_{2} \mathrm{O}_{3}, 4 \% \mathrm{Fe}_{2} \mathrm{O}_{3}+1 \% \mathrm{NiO} \text { и } 4 \% \mathrm{Fe}_{2} \mathrm{O}_{3}+1 \% \mathrm{Cr}_{2} \mathrm{O}_{3}> \\
\text { ABK- } 10+4 \% \mathrm{Fe}_{2} \mathrm{O}_{3}+1 \% \mathrm{CoO}>\mathrm{ABK}-10+4 \% \mathrm{Fe}_{2} \mathrm{O}_{3} 1 \% \mathrm{NiO}> \\
\text { ABK- } 10+1 \% \mathrm{Cr}_{2} \mathrm{O}_{3}>\mathrm{ABK}-10+1 \% \mathrm{CoO}>\mathrm{ABK}-10+1 \% \mathrm{NiO} .
\end{gathered}
$$

To increase the service life and efficiency of the catalyst, the following were studied: activity, conditions for the formation and change in the structure of surface centers with vanadium, iron and manganese ions [9].

Comparative studies of the activity of synthesized catalyst samples and commercial AVK-10 were carried out at temperatures of $523573{ }^{\circ} \mathrm{K}$, gas space velocity of $10000 \mathrm{~m} 3 / \mathrm{h}, \mathrm{NOx}: \mathrm{NH}_{3}=1: 1.2$ (mol) ratio.

The volume fraction of NOx in the tail gas varied within the range: from 0.18 to 0.61 . The duration of each experiment was 20 hours. Table 3 shows the activity of the samples of the catalyst AVK - 10, modified with $\mathrm{Fe}_{2} \mathrm{O} 3-0.057 .0$ (mass parts).

From the table below it can be seen that with an increase in the content of iron oxides in the composition of AVK-10, the activity of the catalyst increases, reaching a maximum at 5.0 (wt. H.). With an increase in the temperature of the process, the degree of purification increases only for samples with a $\mathrm{Fe}_{2} \mathrm{O}_{3}$ content of 0.06-5.0 (mass, h), and in all other cases it decreases, which can be explained by a general decrease in selectivity with

Table. 3

\section{Comparative activity of the AVK-10 catalyst modified with $\mathrm{Fe}_{2} \mathrm{O}_{3}\left(\mathrm{NO}_{\mathrm{x}}: \mathrm{NH}_{3}=1: 1.2\right.$ $(\mathrm{mol}))$, the volume fraction of NOx in the feed gas is 0.5 .}

\begin{tabular}{|c|r|r|r|r|r|r|r|}
\hline \multirow{2}{*}{$\begin{array}{c}\text { Temperature } \\
\text { process 0K }\end{array}$} & \multicolumn{6}{|c|}{$\begin{array}{c}\text { The degree of gas purification from } \mathrm{NO}_{\mathrm{x}}(\%) \text { on the } \\
\text { AVK-10 catalyst, modified with } \mathrm{Fe}_{2} \mathrm{O}_{3},(\text { mass, } \mathrm{h})\end{array}$} & \multirow{2}{*}{ AVK-10 industrial } \\
& 0,06 & од & 1,0 & 4,0 & 5,0 & 7,0 & \\
\cline { 2 - 7 } & 86,5 & 94,1 & 94,4 & 97,2 & 99,01 & 96,5 & 75,6 \\
\hline 513 & 85,9 & 94,2 & 94,7 & 97,6 & 98,50 & 96,7 & 76,4 \\
\hline 533 & 85,7 & 94,8 & 95,1 & 97,1 & 98,30 & 96,4 & 77,8 \\
\hline
\end{tabular}




\begin{tabular}{|l|r|r|r|r|r|r|r|}
\hline 573 & 86,3 & 93,8 & 94,8 & 97,0 & 97,90 & 96,3 & 79,8 \\
\hline
\end{tabular}

an increase in the content of $\mathrm{Fe}_{2} \mathrm{O}_{3}$. The decrease in the activity of the catalyst containing $\mathrm{Fe}_{2} \mathrm{O} 3-7.0$ (mass, h.), As shown by studies by EPR and KTPR, is associated with an increase in the proportion of structures with a bond - $\mathrm{Fe}-\mathrm{O}-\mathrm{V}$ by the appearance of bulk oxide formations with bonds - Fe - O - Fe formation of a free $\mathrm{Fe}_{2} \mathrm{O}_{3}$ phase, as well as a decrease in the reduction temperature. It is known that iron ions have a high oxidizing ability. Paired with vanadium (Fe3+ and $\left.\mathrm{V}_{3++} \mathrm{V}_{4+}\right)$, these properties change and have a positive effect on the activity of the catalyst at F2O3 - 0.06-1.0 (mass, h), in which the bond - $\mathrm{V}$ - $\mathrm{O}-\mathrm{Fe}$-. The deterioration in the selectivity of the catalyst with an increase in the $\mathrm{F}_{2} \mathrm{O}_{3}$ content is explained by the partial realization of a bulk neoplasm with the - Fe - O - Fe - bond and the $\mathrm{F}_{2} \mathrm{O}_{3}$ phase. which at high temperatures acts as a catalyst for the oxidation of ammonia [10]. Approximately the same pattern of changes in activity is observed with the introduction of $\mathrm{MnO}_{2}$ into the composition of AVK-10 - 0.06-7.0 (pbw). Here, also, with an increase in the composition of the catalyst $\mathrm{MnO}_{2}$ from 0.06 to 4.0 (wt, h.), The activity of the catalyst increases, with a further increase to 5.0 (wt. H.), It almost does not change, and at 7,0 (mass, h), the rate of NOx reduction with ammonia begins to decrease.

\section{DISCUSSIONS}

1. A technology has been developed for the utilization of waste industrial alumovanadium catalyst AVK-10 to obtain a modified catalyst AVJK-10 for systems for cleaning tail gases from NOx, based on heat treatment of production wastes with subsequent modification with iron and manganese oxides [11].

2. Using the methods of electron paramagnetic resonance (EPR) and the curve of thermoprogrammed reduction
(KTPR), the mechanism of the modifying action of the additives introduced into the composition of the alumovanadium catalyst AVK-10 separately and in their various combinations was established.

3. The activity and physicochemical properties of modified alumovanadium catalysts have been studied.

4. The properties of the spent industrial catalyst AVK-10 have been investigated. A decrease in the proportion of large catalyst granules from year to year was noted. It is shown that the structural changes in the catalyst are associated mainly with the reduction of $\mathrm{V}_{5}+$ and $\mathrm{V}_{4}+$ ions to the lowest oxidation state.

5. The synthesis was carried out and the study of the properties and characteristics of modified catalysts based on the spent catalyst AVK-10 was carried out.

6. Using a complex of physicochemical research methods, the catalytic systems $\mathrm{A}_{12} \mathrm{O}_{3}-\mathrm{V}_{2} \mathrm{O}_{5}, \quad \mathrm{Al}_{2} \mathrm{O}_{3} \mathrm{~V}_{2} \mathrm{O}_{5}-\mathrm{Fe}_{2} \mathrm{O}_{3}, \mathrm{Al}_{2} \mathrm{O}_{3}-$ $\mathrm{V}_{2} \mathrm{O}_{5}-\mathrm{MnO}_{2}, \quad \mathrm{Al}_{2} \mathrm{O}_{3}-\mathrm{V}_{2} \mathrm{O}_{5}-\mathrm{Fe}_{2} \mathrm{O}_{3}-\mathrm{MnO}_{2}$ have been studied. The factors responsible for the high activity of the catalyst have been determined [12].

\section{CONCLUSIONS}

The prospect of using the waste of leadconcentrating factories as a natural sorbentcatalyst in gemological is substantiated. processes of purification of waste gases of sulfuric acid production.

The proposed chemisorption-catalytic method for purifying waste gas mixtures from sulfur dioxide does not require special preparation of a wet, high-temperature dusty gas. The use of natural materials within the framework of this method allows you to extract from them valuable raw materials - metal oxides[13].

\section{ACKNOWLEDGEMENTS}


An analysis of search methods (generation) and choice of options (decision making) indicates that for the time being the generation of structures of chemicaltechnological systems for gas purification are still unformalized methods that take into account the knowledge of specialists (in the form of heuristics) and their assessment in accordance with the theory expertise[14]. To generate the functional modes of the systems for cleaning gas emissions of industrial enterprises from harmful impurities, it is most expedient to use simulation methods. One of the most effective decision-making methods under the conditions of uncertainty is the expert examination method. Assessing the quality of examinations is based on the selection of subgroups from a group of experts and an analysis of the degree of consistency of their opinions[15]. In the case of multi-criteria design solutions, it is advisable to implement an iterative procedure that takes into account additional information from the preferences of the group.

\section{REFERENCES}

1. Molokanov Yu.K. Processes and apparatuses for oil and gas refining: Textbook for technical schools / Yu.K. Molokanov (series "Processes and Apparatuses of Chemical and Petrochemical Technology"). M :: Chemistry, 1980. 408 e.

2. Margulov R.D., Korotaev Yu.P. Dobycha, podgotovka va transport prirodnogo gaza va kondensa. Spravochnoe rukovodstvo $v$ 2-x tomax. Tom 1. // Nedra. M., 1984. T. 1. S. 360 .

3. Axmetov S.A., Bayazitov M.I., Kuzeev I.R., Serikov T.P. Texnologiya i oborudovanie protsessov pererabotki nefti i gaza // red. S.A. Axmetova / Nedra. SPb., 2006. S. 868

4. Donskix B.D. Razrabotka metodov isledovaniya effektivnosti raboty ustanovok promyslovoy podgotovki prirnnogo gaza: Dissertatsiya na soiskanie uchenoy stepeni k.t.n. // Gazprom VNIIGaz. M., 2011. S. 144.

5. Zhumaev K.K., Iskandarov J.R., Tukhtaev B.B. Development and use of small absorption plants / Questions of science and education №.2(3), Elektronic journal, 2017. - $256 \mathrm{p}$.

6. Iskandarov J.R. Development and use of small-sized absorption installation // Geodesic and surveying problems of cadastral work at the mining and metallurgical industry "Tashkent", 2018. $265 \mathrm{p}$.

7. Mirzaraximov M.S., Iskandarov J.R., Xojibolaev Y.Yu. Analiz vliyaiya gazovyx vybrosov na okrujayushchuyu sredu // Nauka, texnika i obrazovanie 2020. № 2 (66). -S. 5-9.

8. Mirzarakhimov M.S., Hayitov O.G., Musayev M.N., Iskandarov J.R., Umirzoqov A.A. DESIGN OF GAS TECHNOLOGICAL SYSTEMS USING MATHEMATICAL MODELS. / The International journal of analytical and experimental modal analysis. ISSN NO:0886-9367. Volume XII, Issue VII, July/2020. Page: 2263-2273

9. Nasirov U.F., OchilovSh.A., Umirzoqov A.A. Analysis of Development of Low-Power and Man-Made Gold Deposits// International Journal of Academic and Applied Research (IJAAR)ISSN: 2643-9603 Vol. 4, Issue 4, April - 2020, Pages: 71-74. http://ijeais.org/wpcontent/uploads/2020/4/IJAAR200414.pdf

10. Umirzoqov A.A., Jurayev S.J., KaramanovA.N. Economic and mathematical modeling of rational development of small-scale and man-made gold deposits// International Journal of Academic and Applied Research (IJAAR), Vol. 4, Issue 4, April - 2020, Pages: 75-77. http://ijeais.org/wpcontent/uploads/2020/4/IJAAR200415.pdf

11. Hayitov O.G., Umirzoqov A.A., Iskandarov J.R., Suvanov F.R. Prospects for the industrial use of coal in the world and its process of reproducing// Novateur 


\section{Publication's}

JOURNALNX-

A

Multidisciplinary Peer Reviewed Journal, Volume 6, Issue 5, may-2020, Pages:240247. https://journalnx.com/journalarticle/20151009

12. OchilovSh.A., Umirzoqov A.A., KaramanovA.N., Ergashev O.S. Calculation of the Optimal Distance Between ParallelConverged Charges When Exploding High Ledges// International Journal of Academic Management Science Research (IJAMSR), Vol. 4 - Issue 6 (June - 2020), Pages:57-61. http://www.ijeais.org/ijamsr/index.php/ijam sr-4-6-2020/

13. Kazakov A.N., Umirzoqov A.A., Radjabov Sh.K., Miltiqov Z.D. Assessment of the Stress-Strain State of a Mountain Range// International Journal of Academic and Applied Research (IJAAR), Vol. 4 - Issue 6 (June - 2020), Pages:17-21. http://www.ijeais.org/ijamsr/index.php/ijam sr-4-6-2020/

14. Nasirov U.F., Ochilov Sh.A., Umirzoqov A.A. Theoretical Calculation of the Optimal Distance between Parallel-close Charges in the Explosion of High Ledges//(SCOPUS) Journal of Advanced Research in Dynamical and Control Systems - JARDCS, Vol. 12,07special issue, 2020, Pages: 2251-2257. https://www.jardcs.org/abstract.php?id=57 78

15. Umirzoqov A.A., Karamanov A..N., Radjabov Sh. K. Study of the feasibility of using intermediate buffer temporary warehouses inside the working area of the Muruntau quarry// International Journal of Engineering and Information Systems (IJEAIS), Vol. 4, Issue 8, August - 2020, Pages140-142.

http://www.ijeais.org/ijeais/index.php/ijeais $-4-8-2020 /$ 